\title{
PENGARUH INSENTIF, KOMPETENSI, DAN LINGKUNGAN KERJA TERHADAP KINERJA PEGAWAI DINAS PEKERJAAN UMUM KABUPATEN SUKOHARJO
}

\author{
Djuwarto $^{1}$ Istiatin $^{2}$ dan Sri Hartono ${ }^{2}$ \\ ${ }^{1}$ Mahasiswa Manajemen Fakultas Ekonomi Universitas Islam Batik Surakarta \\ ${ }^{2}$ Dosen Fakultas Ekonomi Universitas Islam Batik Surakarta \\ Email: djuwarto73oke@gmail.co.id
}

\begin{abstract}
The purpose of this research are: 1) To determine the effect of incentive, competent, and working environment simultaneously on employee performance Dinas Pekerjaan Umum Kabupaten Sukoharjo. 2) To determine the effect of incentive, competence, and working environment on employee performance Dinas Pekerjaan Umum Kabupaten Sukoharjo.

Data collection method used is the method of questionnaire / questionnaire to 50 employees as respondents. Sampling technique used is random sampling method convenionce sampling. Data analysis methods used include: test instrument (validity and reliability), hypothesis testing (multiple linear regression analysis, $\mathrm{t}$-test, $\mathrm{f}$ and the coefficient of determination (R2).

Results Descriptive analysis showed that most respondents gender male (82\%). All data from the questionnaires have passed the test instrument. For testing $\mathrm{f}$ test result that the value of $F(45.186)>F$ table (3.15) with a probability of $0.000(p<0.05)$. This means Fhitung in the region of Ho rejected, which means a significant difference between the independent variable (incentive, competence, and working environment) simultaneously on the dependent variable (employee performance). From the results of the $t$ test result incentive have a significant positive effect on an individual basis to variable employee performance. This is evident from tcount (5.907)> t table (2.000) with a significance value $<\alpha$ (0.05). Variable competence are also significant positive effect on employee performance. This is because tcount (2.919) $>\mathrm{t}$ table (2.000) with a significance value $<\alpha$ (0.05). Variable working environment is also significant positive effect on employee performance. This is because tcount (4.570) $>\mathrm{t}$ table (2.000) with a significance value $<\alpha$ (0.05). The results of the analysis in this study was obtained R2 values of $0.685(68.5 \%)$. This means that the independent variable (incentive, competence, and working environment) able to contribute $68.5 \%$ influence on the dependent variable (employee performance). While the rest of $31.5 \%$ is influenced by other variables outside of this study as a leadership, compensation, organisational culture, etc.
\end{abstract}

Keywords: Incentive, competence, working environment, employee performance 


\section{PENDAHULUAN}

\section{Latar Belakang Masalah}

Suatu Perusahaan / Instansi tentu mengharapkan pegawainya bekerja secara produktif, dengan pengaturan sumberdaya manusia secara professional. Salah satu faktor yang dapat meningkatkan produktifitas pegawai yaitu kinerja pegawai. Kinerja seorang pegawai merupakan hal yang bersifat individual, karena pegawai memiliki kemampuan yang berbeda-beda dalam mengerjakan tugasnya. Kinerja pegawai yang baik menentukan pencapaian produktifitas perusahaan/ instansi. Namun faktanya tidak semua pegawai memiliki kinerja yang bagus, masih ada pegawai yang memiliki kinerja yang tidak sesuai dengan harapan perusahaan/ instansi.

Kinerja pegawai merupakan hal yang sangat penting dan ini sebagai tantangan tersendiri untuk Instansi dalam mengelola sumber daya manusia, karena keberhasilan suatu perusahaan/ instansi tergantung pada sumber daya manusia yang berkualitas. Menurut Mangkunegara (2000: 45) istilah kinerja berasal dari kata job performance atau actual performance (prestasi kerja atau prestasi sesungguhnya yang dicapai seseorang) yaitu hasil kerja (output) secara tugasnya sesuai dengan tanggung jawab yang diberikan kepadanya. Kinerja perusahaan/ instansi yang buruk dapat disebabkan oleh penurunan kinerja pegawai, hal ini terlihat ketika pegawai tidak dapat menyelesaikan pekerjaan dengan target dan waktu yang ditentukan oleh perusahaan/ instansi.

Usaha untuk meningkatkan kinerja pegawai diantaranya adalah dengan memberikan insentif. Insentif merupakan salah satu jenis penghargaan yang dikaitkan dengan penilaian kinerja pegawai. Semakin tinggi kinerja pegawai, semakin besar pula insentif yang diberikan oleh perusahaan/ instansi. Pemberian insentif dilakukan untuk meningkatkan kinerja pegawai terhadap output yang dihasilkan.

Sumber daya manusia memiliki peranan yang sangat menentukan bagi pengembangan kualitas kerja di setiap organisasi. Mengingat kinerja mengandung komponen kompetensi dan produktifitas hasil, maka kinerja sangat tergantung pada tingkat kemampuan individu. Sebagai sebuah instansi yang besar, Dinas Pekerjaan Umum kabupaten Sukoharjo juga ingin didukung oleh sumberdaya manusia yang memiliki kompetensi agar dapat memberikan pelayanan yang maksimal kepada masyarakat. Kompetensi pegawai yang terdiri dari pengetahuan, keterampilan, dan sikap, harus disesuaikan dengan bidang pekerjaan yang dibutuhkan sehingga dapat menghasilkan kinerja pegawai yang berprestasi. Kompetensi merupakan suatu kemampuan untuk melaksanakan atau melakukan suatu pekerjaan yang dilandasi atas keterampilan dan pengetahuan serta didukung oleh sikap kerja yang dituntut oleh pekerjaan terssebut (Wibowo, 2007: 28).

Wajib bagi suatu perusahaan/ instansi untuk memberikan suasana dan lingkungan kerja yang nyaman dalam pencapaian tujuan yang diinginkan suatu perusahaan/ instansi. Kondisi kerja yang buruk berpotensi menjadi penyebab pegawai mudah jatuh sakit, mudah stress, sulit berkonsentrasi, dan menurunnya 
produktifitas kerja. Jika ruang kerja tidak nyaman, panas, sirkulasi udara kurang memadai, ruang kerja terlalu bising, lingkungan kerja kurang bersih, akan berdampak pada kenyamanan pegawai.

Kondisi seperti inilah yang selanjutnya menciptakan antusiasme untuk bersatu dalam organisasi perusahaan/ instansi untuk mencapai tujuan perusahaan dengan meningkatkan kinerja pegawai. Menurut Putra (2011: 4) lingkungan kerja adalah segala sesuatu yang ada disekitar para pekerja yang dapat mempengaruhi dirinya dalam menjalankan tugas-tugas yang diembankan. Lingkungan kerja mempunyai pengaruh yang signifikan terhadap kinerja pegawai.

Dinas Pekerjaan Umum kabupaten Sukoharjo sebagai dinas yang besar dengan jumlah pegawai yang banyak pasti mempunyai banyak tugas yang harus dikerjakan agar pelayanan terhadap masyarakat menjadi optimal. Untuk dapat meningkatkan pelayanan terhadap masyarakat dibutuhkan kinerja pegawai yang bagus, semakin tinggi kinerja pegawai maka pelayanan kepada masyarakat semakin optimal. Banyak faktor yang dapat mempengaruhi kinerja pegawai diantaranya tidak tepat waktu dalam penyelesaian pekerjaan, menurunnya disiplin kerja, pengaruh lingkungan, pengaruh teman kerja, budaya organisasi dan kurangnya kompetensi.

Sehubungan dengan hal tersebut diatas kemudian timbul pemikiran bagaimana keseluruhan faktor tersebut saling berkesinambungan mempengaruhi kinerja pegawai, untuk itu diperlukan adanya suatu penelitian yang dapat membuktikan bahwa faktor - faktor tersebut mempunyai pengaruh terhadap kinerja pegawai. Atas dasar latar belakang masalah tersebut maka dipandang layak untuk meneliti dengan judul Pengaruh Insentif, Kompetensi dan Lingkungan Kerja Terhadap Kinerja Pegawai Dinas Pekerjaan Umum Kabupaten Sukoharjo.

\section{Rumusan Masalah}

Berdasarkan latar belakang yang dikemukakan diatas, maka secara terperinci masalah yang akan diteliti dan dibahas adalah sebagai berikut:

1. Apakah Insentif, kompetensi dan lingkungan kerja berpengaruh secara simultan terhadap kinerja pegawai Dinas Pekerjaan Umum Kabupaten Sukoharjo?

2. Apakah insentif berpengaruh terhadap kinerja pegawai Dinas Pekerjaan Umum Kabupaten Sukoharjo?

3. Apakah kompetensi berpengaruh terhadap kinerja pegawai Dinas Pekerjaan Umum Kabupaten Sukoharjo?

4. Apakah lingkungan kerja berpengaruh terhadap kinerja pegawai Dinas Pekerjaan Umum Kabupaten Sukoharjo?

\section{Tujuan Penelitian}

Tujuan penelitian yang dilakukan pada Dinas Pekerjaan Umum Kabupaten Sukoharjo adalah sebagai berikut:

1. Untuk mengetahui pengaruh secara simultan insentif, kompetensi dan lingkungan kerja terhadap kinerja pegawai Dinas Pekerjaan Umum Kabupaten Sukoharjo.

2. Untuk mengetahui pengaruh insentif terhadap kinerja pegawai Dinas 
Pekerjaan Umum Kabupaten Sukoharjo.

3. Untuk mengetahui pengaruh kompetensi terhadap kinerja pegawai Dinas Pekerjaan Umum Kabupaten Sukoharjo.

4. Untuk mengetahui pengaruh lingkungan kerja terhadap kinerja pegawai Dinas Pekerjaan Umum Kabupaten Sukoharjo.

\section{TINJAUAN PUSTAKA}

\section{Kinerja pegawai}

Kinerja adalah hasil kerja secara kualitas dan kuantitas yang dicapai oleh seorang pegawai dalam melaksanakan tugasnya sesuai dengan tanggung jawab yang diberikan kepadanya (Mangkunegara 2007: 67). Kinerja sering kali dipikirkan sebagai pencapaian tugas, dimana istilah tugas sendiri berasal dari pemikiran aktivitas yang dibutuhkan oleh pekerja. Karena kinerja pegawai merupakan suatu tindakan yang dilakukan pegawai dalam melaksanakan pekerjaan yang dilakukan perusahaan (Sutrisno, 2009: 95).

Suatu perusahaan/ organisasi tentunya mempunyai tujuan yang harus dicapai, dalam jangka pendek maupun jangka panjang. Untuk mencapainya dibutuhkan kinerja perusahaan/organisasi yang baik. Kinerja perusahaan erat kaitannya dengan kinerja karyawan. Jika kinerja karyawan baik, tentunya akan berdampak positif terhadap kinerja perusahaan.

Kinerja menurut Simamora (2005: 327) adalah tingkat mana karyawan mencapai persyaratan pekerjaan. Sedangkan pengertian kinerja menurut Robbins (2009: 258) adalah merupakan ukuran dari sebuah hasil. Dari pengertian diatas dapat disimpulkan bahwa kinerja karyawan merupakan hasil kinerja yang telah dicapai setiap karyawan, sehingga memberikan ketertiban terhadap perusahaan.

Tujuan penilaian kinerja menurut Robbins (2009 : 259) adalah sebagai berikut :

a) Untuk mengambil keputusan personjalia secara umum, sehingga dapat memberikan informasi yang berhubungan dengan pengambilan keputusan yang penting dalam hal promosi, transfer/pemberhentian.

b) Memberikan penjelasan tentang pelatihan dan pengembangan yang dibutuhkan.

c) Dapat dijadikan sebagai kriteria untuk program seleksi dan pengembangan yang disahkan

\section{Insentif}

Insentif merupakan salah satu jenis penghargaan yang dikaitkan dengan penilaian kinerja pegawai. Semaki tinggi kinerja pegawai, semakin besar pula insentif yang diberikan oleh perusahaan. Pelaksanaan system insentif dilakukan untuk meningkatkan kinerja pegawai terhadap output yang dihasilkan, seperti yang dikemukakan para ahli, diantaranya:

Jiwo wangso dan Kartanto (2003: 101) mengemukakan "Insentif merupakan elemen atau balas jasa yang diberikan secara tidak tetap atau bersifat variabel tergantung pada kondisi pencapaian prestasi kerja karyawan. Menurut Hariandja (2005: 265) bahwa "Insentif merupakan bentuk pembayaran langsung yang dikaitkan dengan kinerja dan Gain Sharing dan diartikan sebagai pembagian keuntungan bagi pegawai akibat 
peningkatan produktivitas atau penghematan biaya."

Berdasarkan uraian diatas dapat dibuat kesimpulan bahwa yang dimaksud dengan Insentif adalah suatu Penghargaan dalam bentuk uang yang diberikan oleh pihak pimpinan kepada pegawai agar mereka bekerja dengan motivasi yang tinggi, berprestasi dalam mencapai tujuan organisasi atau diluar gaji sebagai pengakuan terhadap prestasi kerja dan kontribusi pegawai kepada perusahaan/ instansi.

Jenis-jenis Insentif dalam suatu perusahaan atau instansi harus dituangkan secara jelas sehingga dapat diketahui oleh pegawai dan oleh perusahaan tersebut dapat dijadikan kontribusi yang baik untuk dapat menambah gairah kerja bagi pegawai yang bersangkutan.

Menurut ahli manajemen sumber daya manusia Sondang P. Siagian (2002: 268), jenis-jenis insentif tersebut adalah:

\section{a. Piece Work}

Piece work adalah teknik yang digunakan untuk mmendoronng kinerja kerja pegawai berdasarkan hasil pekerjaan pegawai yang dinyatakan dalam jumlah unit produksi

b. Bonus

c. Komisi

d. Insentif bagi eksekutif

e. Kurva "kematangan"

f. Rencana Insentif Kelompok

Jelas bahwa insentif yang memadai akan mendorong semangat dan gairah tenaga kerja pegawai, sehigga pegawai akan terus menjaga dan meningkatan hasil kerjanya pada akhirnya akan meningkatka keuntungan itu sendiri dalam mencapai tujuan dan sasaran yang ditetapkan, sehingga instansi dan pegawai diharapkan lebih solid dalam membangun kebersamaan menuju kemajua perusahaan atau instansi.

\section{Kompetensi}

Kompetensi sangat diperlukan dalam setiap proses sumber daya manusia, seleksi karyawan, manajemen kinerja, perencanaan dan sebagainya. Robbins (2001: 37) menyebut kompetensi sebagai ability, yaitu kapasitas seseorang individu untuk mengerjakan berbagai tugas dalam suatu pekerjaan. Kemampuan individu tersebut dibentuk oleh dua faktor yaitu faktorm kemampuan intelektual dan kemampuan fisik. Kompetensi adalah suatu kemampuan umtuk melaksanakan atau melakukan suatu pekerjaan atau tugas yang dilandasi atas dasar keterampilan dan pengetahuan serta didukung oleh sikap kerja yang dituntut oleh pekerjaan tersebut. Dengan demikian, kompetensi menunjukkan keterampilan atau pengetahuan yang dicirikan oleh profesionalisme dalam suatu bidang tertentu sebagai sesuatu bidang yang terpenting, sebagai unggulan bidang tersebut (Wibowo, 2007: 28).

Menurut Spencer dalam Wibowo (2007: 28), Menyatakan bahwa kompetensi merupakan landasan dasar karakteristik orang dan mengindikasikan cara berperilaku atau berpikir, menyamakan situasi, dan mendukung untuk periode waktu cukup lama. Selanjutnya Spencer mengemukakan terdapat beberapa faktor yang dapat mempengaruhi kecakapan kompetensi seseorang antara lain keyakinan dan nilainilai, keterampilan, pengalaman, karakteristik pribadi, motivasi, Isu 
emosional, kemampuan intelektual, dan budaya organisasi.

\section{Lingkungan Kerja}

Menurut Supandi (2013: 15) lingkungan organisasi merupakan lingkungan di sekitar pekerjaan yang mempengaruhi semangat kerja kerja seorang individual dalam melakukan pekerjannya. Setiap organisasi dalam hal ini pemimpin harus dapat menciptakan suasana yang mendukung pelaksanaan tugas masing-masing individu dalam organisasi. Harmonisasi tujuan organisasi dengan individu yang terlibat dalam organisasi tersebut penting karena dapat menyamakan liersepsi antara tujuan organisasi dengan tujuan individu. Persamaan visi dan misi antara organisasi dengan para karyawan akan mempercepat target ataupun tujuan yang telah ditetapkan oleh perusahaan.

Seorang pemimpin dalam sebuah organisasi harus mengerti karakteristik individu bawahannya dan mampu memberikan motivasi kepada mereka agar bekerja sesuai dengan yang diharapkan oleh organisasi. Pemimpin harus mampu mendesain dan menciptakan kondisi yang mampu memberikan dukungan kepada setiap individu yang terlibat dalam organisasi. Beberapa hal yang periu diperhatikan dalam hal tersebut adalah :

1) Iklim organisasi yang mendukung

2) Diskusi dengan pemimpin

3) Kesempatan untuk mengembangkan keahlian dan ketrampilan yang dimiliki dalam kaitannya dengan pekerjaannya saat ini.
4) Sistem imbal jasa yang cukup memberikan keadilan bagi para karyawan.

5) Karakteristik individual

Selanjutnya (Gibson et al, 2006: 19) menunjukkan bahwa faktor situasional seperti struktur organisasi, desain pekerjaan, dukungan supervisor, dan adanya dukungan rekan kerja mempunyai hubungan yang signifikan dengan keyakinan diri dalam melakukan transfer pengetahuan dalam pekerjannya. Selanjutnya ia juga menegaskan bahwa lingkungan kerja mempunyai pengaruh terhadap kemampuan dan semangat untuk melakukan transfer pelatihan yang diterimanya pada tugas dan pekerjaannya. Wursanto (2005: 285) menyatakan bahwa faktor lingkungan turut mempengaruhi perilaku manusia dalam bekerja adalah lingkungan dan kondisi masyarakat sekeliling dimana individu itu berada atau bertempat tinggal.

Lingkungan kerja merupakan tempat karyawan untuk melakukan aktivitas kerja setiap harinya. Lingkungan yang diinginkan karyawan yaitu dapat memberikan rasa aman dan nyaman agar karyawan dapat bekerja dengan optimal. Lingkungan kerja juga dapat berpengaruh dengan tingkat emosional karyawan oleh karena itu harus diperhatikan. Karena apabila karyawan memiliki rasa kepuasan terhadap lingkungan kerjanya, maka karyawan tersebut akan nyaman ditempat kerjanya dan waktu untuk melakukan aktivitas kerjanya dilakukan secara efektif otomatis akan berdampak baik dengan kinerjanya dan perusahaan. 


\section{METODOLOGI PENELITIAN}

Penelitian ini menggunakan data primer yang diperoleh dari pegawai Dinas Pekerjaan Umum Kabupaten Sukoharjo. Metode pengumpulan data yang digunakan adalah metode angket/kuesioner dengan 50 pegawai sebagai responden. Teknik pengambilan sample yang digunakan adalah random sampling dengan metode convenionce sampling. Metode analisis data yang digunakan antara lain : uji instrument (validitas dan reliabilitas) dan uji hipotesis (analisis regresi liner berganda, uji t, uji f dan koefisien determinasi $\left(\mathrm{R}^{2}\right)$.

\section{Hipotesis}

Sugiono (2008: 93) menyatakan bahwa "hipotesis merupakan jawaban sementara terhadap rumusan masalah penelitian, oleh karena itu rumusan masalah biasanya disusun dalam bentuk kalimat pertanyaan." Hipotesis dalam penelitian ini adalah :

1) Diduga ada pengaruh secara simultan dan signifikan antara Insentif, Kompetensi, dan Lingkungan Kerja terhadap Kinerja Pegawai Dinas Pekerjaan Umum Kabupaten Sukoharjo.

2) Diduga ada pengaruh positif dan signifikan Insentif terhadap Kinerja Pegawai Dinas Pekerjaan Umum Kabupaten Sukoharjo.

3) Diduga ada pengaruh positif dan signifikan Kompetensi terhadap Kinerja Pegawai Dinas Pekerjaan Umum Kabupaten Sukoharjo.

4) Diduga ada pengaruh positif dan signifikan Lingkungan Kerja terhadap
Kinerja Pegawai Dinas Pekerjaan Umum Kabupaten Sukoharjo.

\section{HASIL PENELITIAN}

Hasil Analisis deskriptif menunjukkan bahwa sebagian besar responden berjenis kelamin laki- laki (82\%). Semua data dari penyebaran kuesioner telah lolos uji instrument.

Hasil uji asumsi klasik:

1. Uji Normalitas

Berdasarkan hasil perhitungan uji Kolmogorov Smirnov dapat diketahui bahwa harga p-value berturut-turut dari kualitas produk, harga, promosi, dan keputusan pembelian adalah sebesar 0,$056 ; 0,065 ; 0,147$; dan 0,055 . Nilai $p$ value ternyata lebih besar dari $\alpha$ ( $\mathrm{p}>$ 0,05), maka dapat disimpulkan bahwa sebaran data nya normal.

2. Uji Multikolinieritas

\begin{tabular}{|l|c|c|}
\hline \multicolumn{1}{|c|}{ Variabel } & $\begin{array}{c}\text { Toler } \\
\text { ansi }\end{array}$ & VIF \\
\hline Insentif & 0,841 & 1,173 \\
Kompetensi & 0,794 & 1,295 \\
Ling.Kerja & 0,696 & 1,457 \\
\hline
\end{tabular}

Berdasarkan tabel diatas dapat disimpulkan bahwa model regresi tersebut tidak terjadi multikolinieritas karena nilai VIF $<10$ dan Tolerasi $>0,1$. 
3. Uji Heteroskedastisitas

\begin{tabular}{|l|c|}
\hline \multicolumn{1}{|c|}{ Variabel } & $\mathrm{t}_{\text {hitung }}$ \\
\hline \hline Insentif & 0,139 \\
Kompetensi & 0,443 \\
Ling.Kerja & 0,598 \\
\hline
\end{tabular}

Berdasarkan tabel diatas nampak bahwa semua variabe bebas memiliki nilai $\mathrm{p}$ diatas 0,05 sehingga semua variabel bebas tersebut bebas dari masalah heteroskedastisitas.

4. Uji Autokorelasi

\begin{tabular}{|l|l|l|}
\hline $\mathrm{dU}$ & $\mathrm{Dl}$ & Durbin Watson \\
\hline 1,613 & 1,236 & 2,111 \\
\hline
\end{tabular}

Berdasarkan tabel diatas terlihat bahwa nilai DW 2,061 lebih besar dari batas atas (dU) yakni 1,613 dan kurang dari (4-dU) $\quad 4-1,613=2,387$ dapat disimpulkan bahwa tidak terdapat autokorelasi.

Untuk pengujian uji $\mathrm{f}$ diperoleh hasil bahwa nilai $F_{\text {hitung }}$ $(45,186)>F_{\text {tabel }}(3,15)$ dengan probabilitas sebesar 0,000 $(p<0,05)$. Hal ini berarti Fhitung berada pada daerah Ho ditolak, yang artinya terdapat pengaruh yang signifikan antara variable independent (insentif, kompetensi, lingkungan kerja) secara simultan terhadap variable dependen (kinerja pegawai). Model persamaan regresi yang dapat disusun adalah sebagai beikut:

$$
\begin{aligned}
\mathrm{Y}= & 4,029+0,348 \mathrm{X}_{1}+0,191 \mathrm{X}_{2}+ \\
& 0,281 \mathrm{X}_{3}
\end{aligned}
$$

Dari hasil uji t diperoleh hasil insentif mempunyai pengaruh positif signifikan secara individual terhadap variable kinerja pegawai. Hal ini terbukti dari nilai $t_{\text {hitung }}(5,907)>t_{\text {tabel }}$ $(2,000)$ dengan nilai signifikansi $<\alpha$ $(0,05)$. Variable kompetensi juga berpengaruh positif signifikan terhadap kinerja pegawai. Hal ini dikarenakan nilai $t_{\text {hitung }}(2,919)>t_{\text {tabel }}$ $(2,000)$ dengan nilai signifikansi $<\alpha$ $(0,05)$. Demikian juga variable lingkungan kerja berpengaruh positif signifikan terhadap kinerja pegawai. Hal ini dikarenakan nilai $t_{\text {hitung }}(4,570)$ $>t_{\text {tabel }}(2,000)$ dengan nilai signifikansi $<\alpha(0,05)$. Hasil analisis dalam penelitian ini diperoleh nilai $\mathrm{R}^{2}$ sebesar 0,685 (68,5\%). Hal ini berarti bahwa variable independent (insentif, kompetensi, dan lingkungan kerja) mampu memberikan sumbangan pengaruh sebesar $68,5 \%$ terhadap variable dependen (kinerja pegawai). Sedangkan sisanya sebesar 31,5\% dipengaruhi oleh variable lain diluar penelitian ini seperti kompensasi, stess kerja, kepemimpinan, budaya organisasi dll.

\section{KESIMPULAN}

Dari hasil pembahasan mengenai pengaruh insentif, kompetensi dan lingkungan kerja terhadap kinerja pegawai Dinas Perkerjaan Umum Kabupaten Sukoharjo dapat diambil beberapa kesimpulan sebagai berikut: 
1. Hasil pengujian menunjukkan bahwa insentif, kompetensi dan lingkungan kerja berpengaruh secara simultan terhadap kinerja pegawai Dinas Pekerjaan Umum Kabupaten Sukoharjo yang ditunjukkan dari hasil Uji $F$ sebesar 45,186 artinya bahwa apabila diberikan insentif bagi pegawai yang memenuhi kriteria kemudian kompetensi pegawai ditingkatkan baik melalui seminar ataupun pelatihan serta lingkungan kerja dibuat senyaman mungkin maka kinerja pegawai juga akan mengalami peningkatan.

2. Insentif berpengaruh positif signifikan terhadap kinerja pegawai Dinas Pekerjaan Umum Kabupaten Sukoharjo, yang ditunjukkan dari nilai hasil uji t sebesar $(5,907)$ artinya bahwa adanya sistem pemberian insentif bagi pegawai yang dapat melaksanakan tugasnya dengan baik dan tepat waktu maka secara otomatis akan meningkatkan kinerja pegawai tersebut.

3. Kompetensi berpengaruh positif signifikan terhadap kinerja pegawai Dinas Pekerjaan Umum Kabupaten sukoharjo, yang ditunjukkan dari nilai hasil uji $\mathrm{t}$ sebesar (2,919) artinya bahwa apabila skill, pengalaman, dan kemampuan pegawai ditingkatkan maka akan meningkatkan kinerja pegawai.

4. Lingkungan Kerja berpengaruh positif signifikan terhadap kinerja pegawai, yang ditunjukkan dari nilai hasil uji $\mathrm{t}$ sebesar (4, 570), artinya bahwa jika tercipta lingkungan kerja yang nyaman bagi pegawai maka hal ini akan meningkatkan kinerja pegawai.
5. Koefisien determinasi pada penelitian ini adalah Square $\left(R^{2}\right) \quad 0,685$ disimpulkan bahwa model yang dipergunakan variabel-variabel bebasnya memberikan sumbangan positif yaitu sebesar 68,5\% terhadap variabel terikat sedangkan $31,5 \%$ dipengaruhi oleh faktor lain seperti kepemimpinan, budaya organisasi, dan sebagainya.

\section{Saran}

1. Hendaknya sistem pemberian insentif yang sudah berjalan selama ini dipertahankan terus dan diperjelas kriteria pegawai yang berhak mendapatkan insentif tersebut.

2. Sebaiknya dalam rangka meningkatkan kompetensi pegawai, perlu adanya suatu kegiatan pelatihan ataupun seminar.

3. Lingkungan kerja yang sudah baik sekarang ini alangkah baiknya lebih ditingkatkan lagi agar pegawai semakin nyaman dalam bekerja.

4. Hendaknya kinerja pegawai yang sudah terlaksana dengan baik dan terkoordinir terus ditingkatkan melalui monitoring dan evaluasi / penilaian secara berkala. 


\section{DAFTAR PUSTAKA}

Arianto, Dwi Agung Nurgoho. 2013. Pengaruh Kedisiplinan, Lingkungan Kerja dan Budaya Kerja Kinerja Tenaga Pengajar. Jurnal Economica Vol. 9, Nomor 2, Oktober 2013. Universitas Islam Nahdlatul Ulama Jepara.

Arikunto Suharsimi, 2006, Prosedur Penelitian Suatu Pendekatan Praktek, Edisi Revisi VI, PT. Rineka Cipta, Jakarta.

Dessler, Gary, 2009. Manajemen Sumber Daya Mnusia. Jilid Dua. Alih Bahasa Agus Dharma. Jakarta : Erlangga Mathis dan Sakson

Ferina, Sukmawati, "Pengaruh Kepemimpinan, Lingkungan Kerja, dan Kompensasi Terhadap Kinerja Karyawan di PT. Pertamina(persero)," Jurnal Ekonomi dan Bisnis, Vol.2 No. 2 (2008)

Gibson, James L, Ivansevic Johyn M \& Donnelley, James H. 2005, Organisasi, Perilaku, Struktur, Proses, Jilid Tiga, Edisi Kedua, Alih Bahasa Nunuk Adiarni, Binarupa Aksara, Jakarta.

Handoko, T Han, 2003, Manajemen, BPFE Yogyakarta, Yogyakarta.

Hariandja, Marihot Tua Efendi. (2005), Manajemen sumber Daya Manusia: Pengadaan, Pengembangan, Pengkompensasian, dan Peningkatan Produktivitas Pegawai. Jakarta: PR Grasindo
Hasibuan, 2009. Manajemen Sumber Daya Manusia, Bumi Aksara, Jakarta.

Henry Simamora. 2005. Manajemen Sumber daya Manusia. Yogyakarta : STIE YKPN.

Istiatin, 2015, Modul Metodologi Penelitian, Unibapress ,Surakarta.

Mangkunegara, Anwar Prabu, 2007. Manajemen Sumber Daya Manusia Organisasi, Cetakan Ketujuh, PT Remaja Rosdakarya Offset, Bandung.

Manulang, M, 2002. Manajemen Personalia Edisi 4, Edisi I BPFE, Yogyakarta.

Maryam, Siti. 2012. Statistik Induktif .Surakarta. Uniba Press.

Panggabean, Mutiara, 2005. Manajemen Sumber Daya Manusia, Cetakan Pertama, Ghalia Indonesia, Bogor.

Pawenang, Supawi dan Eni Kustiyah, 2011, Pengantar Ekonometrika, Idea Press, Yogyakarta.

Robert L. Mathis \& John H. Jackson, 2006. Human Resources Management, Edisi sepuluh, Penerbit Salemba Empat. Jakarta.

Robbins, Stephen. 2011, Perilaku Organisasi, Edisi Kedelapan, Versi Bahasa Indonesia, Jilid II Perason Education Asia. PT. Prengallindo, Jakarta. 
Sugiyono. 2008. Metode Penelitian

Kuantitatif Kualitatif dan R\& D.

Bandung: Alfabeta.

Sutrisno Edy, 2009, Manajemen Sumber Daya Manusia. Kencana Pernada Media Group. Jakarta.

Wangso, Jiwo dan Brotoharsojo, Hartanto. (2003), Merit sistem. PT. Raja Grafindo Persada. Jakarta

Wibowo. 2010. Budaya Organisasi: Sebuah Kebutuhan Untuk Meningkatkan Kinerja Jangka Panjang. Jakarta: Rajawali Pers. 